\title{
테러리즘과 국제개발협력: \\ ‘분쟁과 개발’의 맥락으로 본 테러리즘
}

이현(KOICA ODA연구팀 연구원)

목 차

I. 들어가며

II. 알카에다 3.0 시대: 테러리즘의 프랜차이즈화와 네트워크화

1. 테러리즘의 프랜차이즈화

2. 다국적 또는 초국적 네트워크화한 테러리즘

III. 최근의 테러리즘 경향이 국제개발협력에서 갖는 함의

1. 테러리즘의 온상이 된 분쟁 및 취약국들

2. 국제개발협력: 분쟁 및 테러리즘 해소를 위한 하나의 대안

VI. 결론

제 I장

제파장

제 III장

섹

터

제IV장

\section{I. 들어가며}

2011년 5월 2일(월), 오바마 대통령이 텔레비전 연설을 통해 테러단체 알카에다 (Al-Qaeda)를 조직하고 미국 본토에서 9/11 테러(2001년)을 자행한 오사마 빈 라덴 (Osama bin Laden)을 은신처인 파키스탄 북부 도시 아보타바드(Abbottabad)에서 사살했다고 공식 발표했다.1) 이는 미국이 2001년 9/11 테러 직후인 10월 7일

(일) 오사마 빈 라덴 체포와 알카에다 척결, 그리고 비호 세력인 탈레반을 몰아내기

1) 오바마 대통령은 이날 밤 11 시 긴급 기자회견을 열어 오사마 빈 라덴의 사살을 공식 발표했다. 이에 대해서는 http://www.whitehouse.gov/blog/2011/05/02/osama-binladen-dead를 참고할 것. 
위해 아프가니스탄 전쟁을 시작한지 거의 10 년만의 일이었다. 당시 미 중앙정보국장 이었던 리언 파네타(Leon Panetta)는 오사마 빈 라덴 사망으로 알카에다 조직이 사 실상 '전략적으로 패배(strategic defeat)'했다며 대테러리즘(anti-terrorism) 전쟁의 승리를 기정사실화했다.

그러나 파네타의 공언과 달리 오사마 빈 라덴 사망 이후 3 년이 지난 현재 세계는 여전히 테러리즘으로 몸살을 않고 있다. 특히 중동과 북아프리카에서는 오사마 빈 라덴 사망 이전 못지않게 테러가 하루가 멀다 하고 발생하고 있다. 오히려 오사마 빈 라덴이라고 하는 구심점이 사라지면서 테러리즘이 조직과 활동 범위를 타 지역으 로 확장, 가뜩이나 분쟁에 휩싸여 있거나 분쟁에 취약한 국가들의 안보와 경제를 위 협하고 있다. 관련 전문가들은 이런 테러리즘의 경향을 '테러리즘의 프랜차이즈화 (Franchised Terrorism)' 또는 '알카에다 3.0(Al-Qaeda 3.0)'이라고 부른다.

오사마 빈 라덴 생전, 이슬람 근본주의에 이념적 기반을 둔 테러리즘은 그의 리더 십을 구심점으로 했고, 주요 활동 근거지는 1979년 소련의 아프가니스탄 침공 이후 이슬람 의용군, 즉 무자헤딘(mujahedin)의 대소 저항 거점이었던 아프가니스탄 북부 산악지대였다. 그러나 오사마 빈 라덴이라는 구심점이 사라진 지금 알카에다는 이라 크 알카에다(Al-Qaeda in Iraq, AQI)2), 예멘에 기반을 둔 아라비아반도 알카에다 (Al-Qaeda on the Arabian Peninsular, AQAP), 북아프리카의 이슬람 마그레브 알 카에다(Al-Qaeda in the Islamic Maghreb, AQIM) 등으로 프랜차이즈화 했고, 서 로 네트워크를 구축해 예전에 비해 더 손쉽게, 독자적으로, 그리고 경우에 따라 동시 다발적으로 테러를 자행하고 있다.

이 논문은 오사마 빈 라덴 사후 테러리즘의 경향을 분석하고, 이 경향이 분쟁 및 취약 국가들의 개발협력에 어떤 함의가 있는지 살펴보고자 한다. 참고로 여기서 분 석하는 테러리즘은 이슬람 근본주의와 성전(Jihad)을 표방하는 중동과 북아프리카 지 역을 주요 근거지로 하고 있는 테러 집단들로 한정한다.

2) $\mathrm{AQI}$ 는 근래에 조직 명칭을 이라크-레반트 이슬람국가(Islamic State of Iraq and Levant, ISIL)로 바꿨다. 


\section{II. 알카에다 3.0 시대: 테러리즘의 프랜차이즈화와 네트워크화}

앞서 언급했듯이 최근 테러리즘의 경향은 오사마 빈 라덴 사망을 기점으로 크게 바뀌었다. 대략 두 가지 경향으로 정리할 수 있는데, 하나는 테러리즘의 프랜차이즈 화이고, 다른 하나는 다국적 또는 초국적 네트워크화다.

\section{1. 테러리즘의 프랜차이즈화}

오사마 빈 라덴이 알카에다를 조직한 것은 지금으로부터 약 25년 전인 1988년 또 는 1989년으로 1979년 말 소련이 아프가니스탄을 침공한 이후 이에 맞서 조직된 무 자헤딘에서 떨어져 나온 국제 테러리스트 네트워크(International terrorist network)다. 알카에다는 아랍어로 '기초(the base)'를 뜻하는 말로 '근본주의'를 지칭 하는데, 중동에서 서구 세력이나 이에 동조하는 집단 및 파벌, 정부를 몰아내고 이슬 람 근본주의 국가를 건설하는 것을 목표로 한다(Bajoria and Bruno 2012).

제 I장 제I장

제피장 1991년에 걸프전쟁3)이 끝난 뒤 사우디아라비아에 있는 이슬람 2 대 성지, 즉 메카와 메디나에 미군을 상주시킨 것이 발단이었다. 사우디아라비아는 오사마 빈 라덴의 고 국 - 사우디아라비아의 수도 리야드의 부유한 석유 가문 출신 - 으로 이때 이후 알 카에다는 미국을 포함해 그의 동맹 세력을 중동을 지배하러 온 점령군으로 간주하고 이들을 상대로 테러를 자행하기 시작했다. 그리고 이런 테러 활동의 정점을 찍은 것 이 2001년 9월 11일 발생한, ‘9/11 테러’로 불리는 세계무역센터(World Trade Center)와 미 국방부 청사에 대한 연쇄 테러로 2,843 명이 목숨을 잃었다.

3) 1980년대 냉전종식 후 국제관계의 권력 공백을 틈타 이라크의 후세인이 쿠웨이트가 과거 자국의 영토였다는 이유를 빌미로 무력 침공하자 미국을 주축으로 영국, 프랑스, 사우디아라비아, 소련 등 30 개국이 다국적군을 조직해 쿠웨이트를 지원하면서 벌어진 전쟁(1990년 8월 2일 1991년 2월 28일). 
9/11 테러 직후, 미국은 오사마 빈 라덴과 알카에다 제거, 그리고 비호 세력으로 알려진 탈레반을 축출하기 위해 이들의 본거지인 아프가니스탄을 공격했다. 이렇게 시작한 대테러리즘 전쟁 10년 만인 2011년 5월 2일(월)에 미국이 알카에다의 지도자 이자 정신적 지주였던 오사마 빈 라덴의 사살을 공식 발표했다. 그러면서 오사마 빈 라덴이 사망한 이상 그를 구심점으로 했던 테러리즘이 서서히 잦아들 것이라고 전망 했다. 그러나 예상은 보기 좋게 빗나갔다. 물론 아래〈표 1〉에서 볼 수 있듯이 오사 마 빈 라덴이 사망한 2011년 5월 이후 테러 발생 건수가 반짝 줄기는 했지만 이후 계속 증가 추세에 있다는 것을 알 수 있다.

<표 1> 2011년 5월 오사마 빈 라덴 사망을 전후로 한 테러 발생 건수 추이

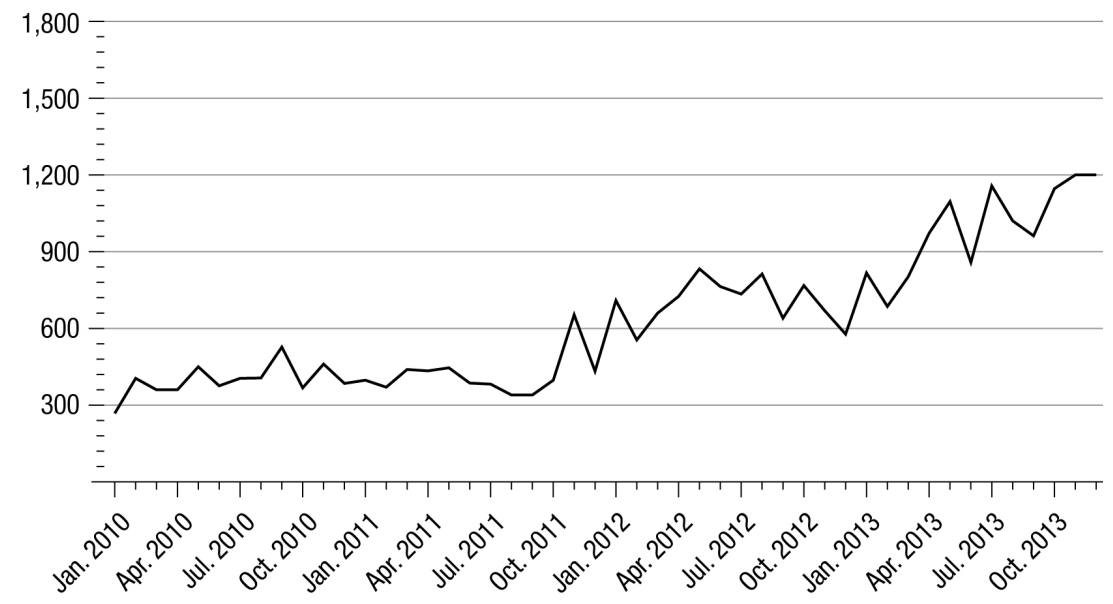

출처: Global Terrorism Database(www.start.umd.edu/gtd)

이 뿐만 아니라 오사마 빈 라덴이라는 구심점을 잃은 알카에다는 몰락이나 해체 대신 지부 또는 점조직 형태로 거듭났고, 세력 범위도 기존 본거지였던 아프가니스 탄을 벗어나 아랍의 봄으로 내분을 겪고 있는 중동 및 북아프리카 국가들, 즉 시리 아, 이라크, 예멘, 이집트, 소말리아, 말리, 수단, 니제르, 나이지리아 등으로 확장했 다(최근 알카에다 활동 현황에 대해서는 아래 〈그림 1〉 참조). 


\section{〈그림 1> 오사마 빈 라덴 사후 알카에다 활동 현황}

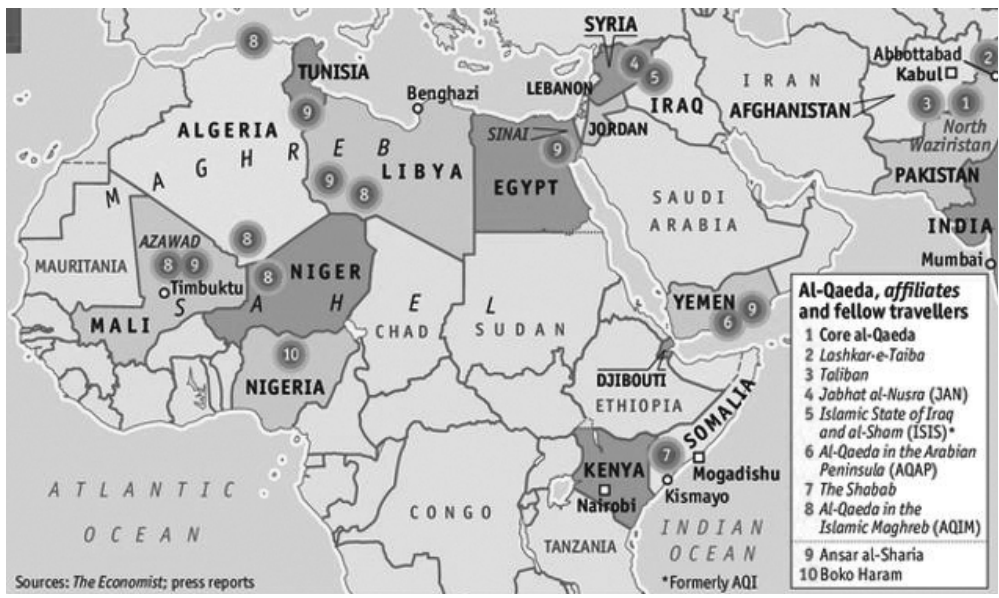

위의 그림에서 알 수 있듯이 현재 알카에다는 아프가니스탄을 본거지로 하는 기존 의 중앙 조직(Core Al Qaeda)을 비롯해 현재 이라크 북부 모술을 거점으로 이슬람 국가를 선포한 이라크-레반트 이슬람국가(Islamic State of Iraq and al-Sham, ISIS $)^{4)}$, 아라비아반도 알카에다(AQAP), 이슬람 마그레브 알카에다(AQIM), 시리아의 자브하트 알 누스라(Jabhat al-Nusra) 등으로 지부화 또는 독자 세력화했고, 기존 의 자생적이었던 다른 알카에다 연계 조직들, 예를 들어 소말리아의 알샤바브 (Al-Shabaab) - '젊은이'라는 뜻 — 와 나이지리아의 보코하람(Boko Haram) - '서 구 교육은 죄악'이란 뜻 - 등과 네트워크를 구축해 전 방위적인 테러와 살인, 강도, 인질, 밀수 등 조직화한 범죄(organized crimes)를 저지르고 있다.

4) ISIS는 알카에다 이라크 지부(AQI)가 발전한 조직으로 2013년 4월에 만들어졌다. 정확 한 조직원 수는 알려져 있지 않는데, 대략 7,000 명에서 10,000명 정도로 추산한다. 과 거 사담 후세인 집권 시절 지배 집단이었던 군대 및 경찰 출신 인사들이 주축을 이룬 다. 레반트란 시리아를 중심으로 레바논과 요르단을 아우르는 지명으로 '해 뜨는 곳'이 란 뜻이다. 이슬람어로는 알샴(al-Sham)이라고 부르는데, 그래서 영미권에서는 Sham 의 'S'를 따서 ISIS라고 표기하지만, 알카에다는 al-Sham보다 Levant란 표기를 더 선 호한다고 한다. 이슬람의 두 정파, 즉 수니파와 시아파 중 수니파인 ISIS는 이라크-시 리아-레바논-요르단에 이슬람국가를 수립하는 것을 목표로 하는데, 지난 6월 29일 현 재 무장 점령한 이라크 북부 지역과 내전 중인 시리아 북동부 지역에 칼리페이트 (Caliphate), 즉 이슬람 제후국을 선포하고 조직 명칭도 이슬람국가(Islamic State, IS) 로 변경했다.

이와 관련해서는 http://www.nytimes.com/interactive/2014/06/12/world/middleeast/ the-iraq-isis-conflict-in-maps-photos-and-video.html\#를 참고할 것. 
미 중앙정보국(CIA) 정보 분석관 출신으로 현재 브루킹스연구소 산하 사반중동정 책센터(Saban Center for Middle Eastern Policy) 수석연구원으로 있는 브루스 리 델(Bruce Riedel)은 최근 알카에다의 프렌차이즈화를 '알카에다 3.0'이라고 부른다. 리델에 따르면, 알카에다 1.0 , 즉 1 세대는 오사마 빈 라덴이 아프가니스탄에서 알카 에다를 조직하고 2011년 9/11 테러를 일으킨 시점까지, 알카에다 2.0은 9/11 테러 이후 오사마 빈 라덴 사망 시점까지, 알카에다 3.0 은 오사마 빈 라덴 사후 지역별로 점조직화한 알카에다 세력을 지칭한다(Riedel 2012). 이렇게 점조직화한 알카에다 3.0 의 주요 특징 가운데 하나는 바로 각 조직이 자생적 성격을 띠는 동시에 조직들 간 네트워크를 구축해 서로 정보를 공유하며 테러를 기획하고 실행한다는 것이다. 즉, 기존에 테러를 기획하고 명령을 내리던 중앙 조직이 큰 의미를 갖지 않게 됐다. 알카에다 3.0 의 등장은 테러 조직의 수적 증가 외에도 과거 중앙집권적인 '경성 조 직'에서 자생적이고 네트워크화한 '연성 조직'으로 전환함에 따라 테러 조직을 통제하 거나 테러를 사전에 감지해 대비하는 것이 그만큼 어려워졌다는 것을 의미한다.

\section{2. 다국적 또는 초국적 네트워크화한 테러리즘}

사실, 테러리즘의 네트워크화 문제는 새로운 이야기가 아니다. 이는 테러리즘의 네 트워크화를 알카에다 3.0 의 고유 성격으로 규정하는 데는 무리가 있다는 뜻으로 다 만 여기에서 테러리즘의 네트워크화를 이야기하는 것은 알카에다가 프렌차이즈화 하 면서 네트워크를 활용한 정보 교환이나 테러 기획이 예전에 비해 더 쉽고 빈번하게 이뤄지고 있다는 것을 강조하기 위해서다. 2001년 9/11 테러도 마찬가지지만, 알카 에다 2세대가 주도한 테러들, 예를 들어 2002년 인도네시아 발리 나이트클럽 테러, 2005년 런던 지하철 테러, 그리고 2008년 인도 뭄바이 호텔 및 지하철 연쇄 테러 같은 굵직한 테러 사건들은 테러리즘의 네트워크화, 즉 테러 기획과 명령을 담당하 는 알카에다 중앙 조직과 지역별 수행 조직 간의 네트워크에 기반을 뒸다. 테러가 일어난 장소 - 세계 각지에서 몰려든 사람들로 북적이는 대도시 중심부 - 도 장소 거니와 현지 시민권자가 포함된 테러리스트들 그리고 테러로 인한 다국적 피해자들 이 이런 네트워크의 전지구적 파급력을 보여준다. 그래서 경우에 따라서는 알카에다 를 어떤 실체가 있는 조직이라기보다는 '네트워크' 자체로 보기도 한다. 앞서 알카에 다를 국제 테러리스트 네트워크로 부른 것도 같은 맥락에서다. 
물론 여기서 말하는 네트워크는 단지 테러리즘 조직들 간의 네트워크만이 아니라 정보통신을 뜻하는 네트워크를 포괄한다. 알카에다 조직들은 인터넷이나 사회관계망 서비스(social network service, SNS) 등 국경을 초월하는 정보통신망을 활용해 서 로 정보를 교환하는 것은 물론 이슬람 원리주의에서 폭발물 제작 방법, 나아가 구체 적인 테러 기법까지 전파하는데 열을 올리고 있다. 이슬람 원리주의의 관련 여부를 떠나 최근에 사이버-테러가 증가하고 있는 것도 이런 네트워크화의 한 현상으로 볼 수 있을 것이다. 문제는 이 때문에 누구든 마음만 먹으면 언제 어디서든 테러를 자 행할 수 있다는 것인데, 이런 테러를 '외로운 늑대형(lonely wolf)' 테러라고 부른다. 외로운 늑대형 테러란 어느 조직이나 단체에 속하지 않은 익명의 누군가가 사회에 불만을 품고 아무런 이유나 사전 예고 없이 테러를 자행할 수 있다는 점에서 테러리 즘의 불확실성, 무차별성, 익명성을 가중하고 있다(Thomson 2013). 대표적인 예로 2011년 7월 노르웨이 우토야섬에서 발생한 무차별 총기 난사로 77명이 사망한 사건 과 2013년 4월 보스턴 마라톤 대회에서 일어난 사제 폭발물 테러로 3명이 사망하고 180 여 명이 부상한 사건이다. 두 사건 모두 조직화한 테러 단체와 어떠한 연관도 없 는 인물이 일으킨 테러이자 인터넷을 통해 범행 수단을 학습했다는 점에서 공통점이 있다.

이런 테러리즘의 네트워크화가 오사마 빈 라덴 사망 이후 더욱 가속화하고 있다. 『시사 $\mathrm{IN}_{\S}$ 의 김영미 국제문제 전문 편집위원은 알카에다 3.0 을 “철저히 프랜차이즈 화한 네트워크 조직'(김영미 2013a)으로 정의한다. 오사마 빈 라덴 사망으로 과거 조 직을 훈련하고 명령을 내리던 구심점이 사라졌음에도 〈표 1〉에서처럼 테러리즘이 잦 아들지 않고 있는 것, 아니 오히려 새로운 전성기를 맞이한 것처럼 보이는 것은 철 저히 프랜차이즈화함으로써 세력과 위험을 분산하고 네트워크화한 덕분이다. 그리고 역설적으로 이런 네트워크화 덕분에 오사마 빈 라덴이라는 구심점이 사라졌음에도 알카에다가 중동 및 북아프리카 등지에서 자생적인 조직으로 거듭날 수 있었던 것으 로 보인다.

그리고 지난해 9월 21 일(토), 알카에다 3.0, 다시 말해 '철저히 프랜차이즈화한 네 트워크 조직'이 향후 어떤 성향을 띠고 어떠한 방식의 테러를 일으킬지 가늠해 볼 수 있는 테러가 발생했다. 바로 케냐 수도 나이로비에서 발생한 웨스트게이트 쇼핑몰 
테러 사건이다. 민간인 사망자 67명과 부상자 170 여 명을 남긴 이 테러는 소말리아 에 근거지를 둔 알샤바브의 소행이었다. 현재 아흐메드 압디 고다네(Ahmed Abdi Godane)가 이끌고 있는 알샤바브는 2006년에 소말리아에서 세력화한 이슬람 법정연 대(Islamic Courts Union, ICU) 안에서 조직된 테러 단체로 케냐가 소말리아 내전 에 개입해 이슬람 법정연대를 몰아낸 것을 앙갚음하기 위해 테러를 계획했다. 이 테 러가 최근 테러리즘 경향에서 시사하는 것은 이전의 테러가 주로 아랍계 현지인이 관여했던 것과 달리 비아랍계 백인을 포함해 다국적 테러리스트들이 주도했다는 것 이다. 즉, 아랍계 현지인은 한 명도 없었다. 보고에 따르면, 이 테러를 자행한 테러 리스트들은 2005년 런던 지하철 자폭 테러범의 아내로 '화이트 위도(white widow)', 즉 백인 아내로 알려진 영국인 사만다 루스웨이트(Samantha Lewthwaite)를 포함해 미국에서 백인으로 분류되는 아랍계 미국인 3명이었다(Harding 2013). 다시 말해, 알카에다가 프랜차이즈화 및 네트워크화하면서 순수 아랍계 세력에서 다국적 또는 초국적으로 세력으로 재구성되고 있는 것으로 테러리즘이 한 단계 더 진화했음을 보 여준다. 이는 기존에 이슬람 극단주의자를 대상으로 했던 테러 감시체계의 무력화 또는 와해를 의미하는 것은 물론 국경을 초월한 이동이 자유로운 시대에 그만큼 전 세계가 테러 공격에 취약해 졌다는 것을 반증하기도 한다.

\section{III. 최근의 테러리즘 경향이 국제개발협력에서 갖는 함의}

오사마 빈 라덴 사후 이슬람 근본주의 성향의 테러리즘이 철저히 프랜차이즈화한 네트워크 조직으로 변모하면서 기존의 대테러리즘도 전략 수정이 불가피해졌다. 미 국과 영국이 주도한 기존의 대테러리즘은 $9 / 11$ 테러를 기획한 오사마 빈 라덴과 알 카에다 제거에 중점을 두었고, 따라서 알카에다를 배후에서 지원하는 탈레반을 몰아 내기 위해 아프가니스탄 전쟁을 시작했다. 비록 알카에다를 조직한 오사마 빈 라덴 제거는 성공했지만, 탈레반은 여전히 건재하고 중동 및 북아프리카에서는 새로운 자 생적 테러 조직들, 즉 알카에다 연계 조직들이 활개치고 있다. 설상가상으로 미국은 2008년 금융 위기로 경제위기에 봉착하면서 재정적자가 천문학적으로 불어 2003년 3 월 이라크 침공 이후 8년만인 2011년 12 월 이라크에서 완전히 철군했고, 미국 역사 상 가장 긴 전쟁을 치르고 있는 아프가니스탄에서도 2016년 말까지 철군을 계획한 상태다. 강공일변도였던 대테러리즘 전쟁의 1 막이 별다른 성과 없이 끝날 공산이 커 
진 것이다. 하지만 테러리즘이 여전히 국가, 지역, 국제 질서를 위협하는 주요 원인 이라고 할 때 테러리즘 성격 변화에 맞는, 다시 말해 프랜차이즈화하고 네트워크화 한 테러리즘에 맞은 새로운 대테러리즘 전략이 필요하다. 대테러리즘의 2 막을 준비 할 때인 것이다. 최근에 분쟁 및 취약국들의 평화구축과 개발지원에 초점을 두고 있 는 국제개발협력이 이에 대한 해답은 아니더라도 대안 모색을 위해 하나의 참고가 될 수 있을 것이다.

\section{1. 테러리즘의 온상이 된 분쟁 및 취약국들}

먼저, 앞으로 돌아가 〈그림 1〉을 눈여겨보자. 그림에서 알 수 있듯이 최근의 알카 에다 점조직들과 연계 조직들이 주로 분쟁 지역을 주요 본거지로 삼고 활동하고 있 다는 것을 알 수 있다. 여전히 미국이 대테러리즘을 벌이고 있는 아프가니스탄과 인 접국인 파키스탄, 2011년 아랍의 봄 당시 내전이 발생해 지금까지 3 년 넘게 내전을 치르고 있는 시리아, 최근 ISIS의 북부 지역 점령으로 사실상 내전 상태인 이라크, 중앙 정부 조직이 붕괴해 국가라고도 하기 힘든 소말리아, 그 외 예멘, 리비아, 나이 지리아 등 모두 분쟁 및 취약국들이다(취약국에 대해서는 The Fund for Peace 2014 를 볼 것). 기존의 알카에다 조직이 오사마 빈 라덴 사후 프랜차이즈화 할 수 있었던 것은 2011년 초 '아랍의 봄'(중동 민주화) 이후 중동 및 북아프리카 지역이 분쟁 지역 화하면서 테러 단체를 조직하고 활동할 수 있는 환경이 조성됐기 때문이다. 솔직히 이런 분쟁 상황은 2001년 9/11 테러 이후 대테러리즘의 일환으로 테러 조직들과 테 러리스트들에 대한 감시 및 국제 공조가 강화됐고, 이에 더해 미국이 장기간 이어진 아프가니스탄 전쟁으로 재정적자가 누적되고 미군 사망자가 늘면서 국내 여론이 악 화되자 이를 잠재우기 위해 드론(무인기)를 도입해 무차별 공격을 가하면서 운신의 폭이 좁아진 테러 조직들에게 호기나 다름없다. ‘긁어 부스럼’이라는 표현처럼 강공 일변도의 대테러리즘이 분쟁 지역을 기반으로 테러리즘이 확산하는데 직간접적으로 기여한 것이다.

테러가 폭력과 분쟁과 공포를 조장하고 이로부터 물질적, 비물질적 이득을 취한다 는 것은 테러리즘의 고전 이론에 속한다. 물론 이 이론은 아직도 유효하다. 그리고 앞서 언급했듯이, 사이버-테러라는 말이 유행하는 데서 알 수 있듯이 전 세계가 네 
트워크로 연결된 지금 정보의 각축장인 네트워크가 또 다른 테러의 온상이 됐다. 간 단히 말해 이런저런 분쟁이 각종 테러의 온상이 되고 있는 것이다. 그런데 분쟁이 테러의 온상이라고 말할 때 주의해야 하는 것은 분쟁도 시기나 지역에 따라 양상이 변화해 왔다는 것이다.

우선, 전 세계 정보의 각축장인 사이버 세계를 논외로 할 경우, 최근의 테러리즘이 온상으로 삼고 있는 분쟁은 기본적으로 환경, 빈곤, 불평등, 인종, 종파 등 복합적인 요인이 매개된 내전(civil wars)의 양상을 띤다. 이런 분쟁은 전 세계가 세계화되고 정보화가 급격히 진행하면서 어느 한 나라 또는 지역에서 일어난 분쟁이 다른 나라 와 지역에 파급되는 초국적 경향을 띠는 특징이 있다. 런던정경대학교 국제관계학 교수인 매리 캘도어(Mary Kaldor) 교수는 이런 분쟁을 과거 국가 간 전쟁, 즉 낡은 전쟁(old wars)과 구분해 새로운 전쟁(new wars)이라고 부른다(Kaldor 2006). 다시 말해, 냉전시기의 테러리즘이 동-서 이념 갈등을 온상으로 했고, 탈냉전 이후에는 서구의 신자유주의 세계화와 이슬람 근본주의의 충돌을 온상으로 했다면, 지금의 테 러리즘은 복합적이고, 종합적이고, 초국적인 분쟁을 온상으로 하고 있다. 비록 이슬 람 근본주의가 애초에 내세웠던 반미, 반유대주의, 반세계화 논리가 사그라진 것은 아니지만, 테러리즘의 온상인 분쟁의 양상이 달라진 만큼 대테러리즘 전략의 수정은 당연한 것이다.

현재 알카에다 3.0 은 중동과 북아프리카의 분쟁 상황을 활용해 도처에서 세력을 키 워나가고 있고, 비록 여전히 이슬람 교리와 성전을 전면에 내세우기는 하지만, 테러 활동을 통해 정치적, 이념적 이득보다 경제적 이득을 취하는데 관심이 큰 조직화한 범죄 집단으로 변모하고 있다. 최근의 테러리즘은 분쟁 지역에서 분쟁으로 삶의 터전 이 파괴돼 당장의 생계는 물론 장래가 불투명한 젊은이들을 조직원으로 충원하고, 분 쟁 상황을 십분 활용해 살인, 강도, 인질, 밀수 등을 서슴지 않고 있다(Sandler and Enders 2008, 1). 분쟁 지역을 온상으로 하고 있는 테러리즘이 분쟁 지역의 인도주 의, 빈곤, 불안, 불평등을 가중하고 있는 것이다. 이러한 테러리즘 경향에 대해 기존 의 강경 대응 방침을 고수하는 것은 사안의 본질을 이해하고 문제의 해답을 찾는데 적합하지 않다. 최근의 테러리즘이 프랜차이즈화하고 네트워크화한 마당에 어느 한 세력이나 조직을 제거한다고 해서 테러리즘 전체가 타격을 받지 않는다. 물론 분쟁을 
해결하고 평화를 구축한다고 해서 테러리즘이 완전히 사라진다는 보장도 없지만, 현 재 분쟁이 테러리즘의 온상이라고 할 때 테러리즘을 해소하기 위해 분쟁 문제를 심각 하게 인식하고 이에 적극 개입해야 하는 것은 시대적 과제가 됐다.

\section{2. 국제개발협력: 분쟁 및 테러리즘 해소를 위한 하나의 대안}

지난 8월 14일(수), 프랑스에 본부를 두고 있는 '국경없는 의사회(Doctors without Borders)'가 1991년 이후 22년 동안 인도주의 목적의 의료 활동을 해온 소말리아에 서 철수한다고 발표했다. 철수 이유는 소말리아의 인도주의 상황이 외부의 도움이 필요 없을 만큼 나아졌기 때문이 아니라 인도주의 활동을 할 수 없을 만큼 상황이 악화됐기 때문이다. 국경없는 의사회의 우니 카루나카라(Unni Karunakara) 국제회 장은 소말리아에서 인도주의 활동을 해온 지난 22 년 동안 케냐 나이로비 쇼핑몰 테 러를 일으킨 알샤바브를 포함한 무장 단체에 의해 소속 활동가 16 명이 살해되는 등 감당하기 힘들 정도로 잦은 살인, 강도, 납치, 협박에 시달렸지만 '소말리아 당사자 들', 즉 소말리아 정부와 부족 원로 등 사회 지도자들이 이에 대해 우려하고 대책을 세우려 하기보다는 수수방관한 채 용인하는 분위기에서 더 이상 안전을 담보할 수 없다는 판단에 철수하기로 했다고 발표했다.5) 목숨을 담보로 분쟁 지역을 마다 않고 적극적으로 인도주의 활동을 펼쳐온 국경없는 의사회가 안전을 이유로 철수 결정을 내린 것은 아주 이례적인 일이다. 그만큼 최근의 테러리즘이 인도주의 활동에 큰 장 애 요인이 되고 있다는 반증일 것이다.

이 외에도 중동과 북아프리카의 분쟁 국가들을 거점으로 하고 있는 알카에다 점조 직들과 연계 조직들의 소행으로 밝혀진 살인, 납치, 강도, 밀수 등 조직화한 범죄는 수도 없이 많다. 예를 하나 더 들어보자. 차드, 말리, 니제르, 리비아, 알제리 등 북 아프리카를 거점으로 하는 이슬람 마그레브 알카에다(AQIM)는 외국인을 인질로 잡 은 뒤에 받아낸 몸값으로 조직을 운영하고 세력을 확장하는 것으로 정평이 나있다. 데이비드 코언(David S. Cohen) 미 재무부 차관은 이슬람 마그레브 알카에다에 지 급된 인질 1 명당 몸값이 2010년에 450만 달러(한화 약 48억 원)이었고, 2011년에는

5) 이에 대해서는 http://www.nytimes.com/2013/08/15/world/africa/doctors-withoutborders-to-pull-out-of-somalia.html?smid=fb-share\&_r=2\& 를 참조할 것. 
540만 달러(58억 원) 정도였다고 말했다(김영미 2013b). 뿐만 아니라 이들 테러 단 체가 자금을 조달하기 위해 국제사회의 원조 물자 및 기금을 타깃으로 범죄를 저지 른다는 것은 이제 진부한 이야기가 됐다. ${ }^{6)}$ 문제는 겉으로 이슬람 성전을 표방하는 무장 테러 단체들의 이와 같은 조직화한 범죄가 분쟁을 가중 또는 영속시키는 것은 물론 국제사회의 인도지원이라든가 개발지원을 저해 또는 무력화하는 요인으로 작용 한다는 것이다.

현재 국제개발협력 공동체에서 분쟁과 개발의 상관성에 대한 인식이 날로 높아가 고 있다. 지난 2011년 11월 부산에서 열린 세계개발원조총회(Fourth High-Level Forum on Aid Effectiveness, HLF-4)에서 채택한 〈취약국 개입을 위한 뉴딜(New Deal for Engagement in Fragile States)〉(이하 〈뉴딜〉)이 이를 단적으로 대변한 다. 〈뉴딜〉에 따르면 i ) 전 세계 15 억 인구가 분쟁 중이거나 분쟁에 취약한 국가에 서 살고 있고, ii) 취약국의 $70 \%$ 가 1989 년 냉전 종식 이후 여전히 분쟁 상태에 놓여 있으며, iii) 공적개발원조(official development assistance, ODA)의 30\%가 분쟁 및 취약 상황에 쓰이고 있음에도 불구하고 분쟁 및 취약국들 중 새천년개발목표 (Millenium Development Goals, MDGs)를 하나라도 달성한 나라가 없다고 한다. 그만큼 분쟁 및 분쟁에 취약한 상황이 빈곤의 악순환을 낳고 있고, 또 국제사회의 지원 노력을 저해하고 있다는 뜻이다(Piazza 2006; World Bank 2011; Geneva Declaration Secretariat 2011).

그런데 이런 분쟁과 개발의 상관성에 대한 인식에서 흥미로운 것은 테러리즘을 국 제개발협력의 틀 내에서 바라보는 시각이 아직은 일반적이지 않다는 것이다. 물론 넓은 의미에서 테러리즘이 분쟁의 하나 또는 한 측면이라고 할 때 분쟁과 개발 담론 이 이를 아주 간과하거나 논외로 하고 있는 것은 아니다. 하지만 대체로 테러리즘의 대명사격인 알카에다가 이슬람 근본주의를 앞세워 서구 중심의 세계 질서를 거부 또 는 위협하다보니 항상 눈엣가시로 제거 대상으로 인식되는 경향으로 인해 기본적으 로 인도주의에 기반을 둔 국제개발협력의 인식틀에서 제대로 논의한 적은 없다. 이 렇게 된 데에는 이미 통념이 된 오리엔탈리즘(orientalism)으로 불리는 서구의 비서

6) 이에 대해서는 Paul Collier, Bottom Billion, Oxford: Oxford University Press, 2008; 류현 역, <빈곤의 경제학>, 서울: 살림, 2010 을 참고할 것. 
구 사회에 대한 인식, 특히 이슬람 근본주의를 바라보는 서구의 이데올로기적 편향 이 한 몫 했다고 본다(Said 1979). 그리고 진부하기는 하지만 새뮤얼 헌팅턴(Samuel Huntington)의 '문명충돌론’도 같은 선상에 있다(Huntington 2011). 사정이 이렇다 보니 서구의 주요 선진국들이 주도하는 국제개발협력도 이것에서 자유로울 리 없다. 지금까지 테러리즘은 극단주의와 폭력에 찌든 '악의 축(axis of evil)'으로 척결 대상 이었을 뿐 기본적으로 대화나 협상의 대상이 아니었다. 물론 대화가 없었던 것은 아 니다. 현재 아프가니스탄 전쟁을 지속하고 있는 미국은 당초 2014년 말 철군 계획 (현재 2016년으로 연기)을 세우면서 탈레반과 포로교환 맞교환 협상을 진행하는 등 평화협상을 벌였다. ${ }^{7)}$ 이와 같은 대화 노력이 앞으로 다른 테러집단과도 이뤼질 수 있을지는 미지수지만, 앞서 살펴 본대로 강공일변도의 대테러리즘은 실패했고, 따라 서 테러리즘이 분쟁을 온상으로 범죄조직화하고 있는 지금 이를 해결하기 위해 인식 의 전환이 요구되고 있다.

최근 국제개발협력에서 대두하고 있는 분쟁 및 취약국에 대한 개발지원 노력이 테 러리즘의 프랜차이즈화와 네트워크화에 따른 대테러리즘 전략 수정에 시사하는 바가 있다. 하지만 현 시점에서 국제개발협력의 맥락에서 어떤 대테러리즘 전략을 세울 수 있을지 구체적인 대안이나 정책을 제시하는 것은 시기상조다. 다만, 앞서 언급한 〈뉴딜〉처럼 최근 국제개발협력이 분쟁 및 취약국 지원에 관심을 갖고 있다는 것이 희망이라면 희망일 것이다. 무엇보다 〈뉴딜〉은 분쟁의 원인과 성격을 이해하려는 노 력, 그리고 이에 기초해 분쟁 당사자들이 참여하는 협의체를 중심으로 분쟁해결, 평 화구축, 국가건설, 경제개발을 논의하고 이를 제도화하려고 한다는 것이 핵심이다. 이 외에도 목표 달성 시한을 1년 앞두고 있는 MDGs의 후속 논의인 'Post-2015' 개 발 의제 논의에서도 이런 인식의 전환을 확인할 수 있다. 'Post-2015'는 MDGs가 분 쟁 및 취약성 문제를 주요 목표로 다루지 않은 것을 보완하는 차원에서 평화와 안보,

7) 2013년에 미국은 당초 2014년 말 아프가니스탄 철군을 앞두고 탈레반과 평화협상을 맺 기 위해 탈레반이 카타르 도하에 설치한 탈레반정치사무소에서 포로 맞교환 등 대화를 시도한 적이 있다. 이 대화는 아프가니스탄 정부의 반대로 무산되기는 했지만, 미국이 테 러단체와 벌인 협상이라는 데서 사태 해결의 평화적 의지를 보인 중요한 신호였다. 그리 고 지난 6월에 미국은 쿠바 관타나모 수용소에 수감된 탈레반 포로 5명과 탈레반에 붙잡 혀 있는 마지막 미군 포로인 보 버그달(Bowe Bergdahl) 병장과 맞교환하는 것에 합의했 다. 이에 대해서는 http://online.wsj.com/articles/u-s-taliban-prisoner-exchangerevives-hopes-for-afghan-peace-talks-1401573782를 참고할 것. 
제도와 거버넌스를 주요 의제로 설정하기 위해 폭넓은 논의를 진행하고 있다(UN System-wide Task Force 2012; UNHLP 2013; UN General Assembly 2013). 물 론 평화와 안보를 개발협력 의제로 설정하는 것에 대해 반발이 없는 것은 아니다. 왜냐하면 평화와 안보는 제 2 차 세계대전 이후 줄곧 유엔안보리의 주요 사안이었고, 또 항상 평화와 안보는 일국의 ‘주권’과 밀접한 연관이 있기 때문에 ‘주권침해’를 우 려하는 일부 개발도상국가들이 내켜하지 않거나 반대하고 있는 것이다(Slotin and Elgin-Cossart 2013).

이런 경향은 최근의 국제정치에서도 찾아볼 수 있다. 우선, 2013년 8월, 2011년부 터 내전이 휩싸인 시리아에서 화학무기 공격으로 추정되는 사건이 발생하자 국제사 회는 미국 주도의 군사 응징을 두고 찬반 논란에 휩싸였다. 결국 이 논란은 국제사 회의 관리 및 통제 아래 시리아가 보유하고 있는 화학무기를 전량 폐기하는 것으로 봉합됐다. 즉, 군사적 해법보다 외교적, 평화적 해법이 지지를 받은 것이다. 지난해 11 월 이란과 $\mathrm{P} 5+1$ - 유엔 안전보장이사회 5 개 상임이사국과 독일 - 사이에 맺은 이란 핵 협상 잠정타결도 이런 경향을 대변한다. 서로 종교, 이데올로기, 정치체제가 다르다고 해서 무조건 배척하는 것이 아니라 대화와 타협을 통해 문제를 해결할 수 있다는 의지 또는 가능성을 보여준 것이다.

다시 말하지만, 국제개발협력이 테러리즘을 근절할 것이라는 확실한 보장은 없다. 이것은 분쟁에도 똑같이 적용할 수 있다. ODA가 분쟁을 해결할 수 있다는 보장은 어디에도 없다. 하지만 일말의 가능성은 있다. 중요한 것은 이에 대한 관심과 인식이 고, 더구나 이를 해결하기 위해 국제사회가 이미 공동으로 노력하고 있다. 배타와 적 대가 아닌 이해와 포용, 그리고 협력을 전제로 한다면 불가능한 일은 아닐 것이다. 


\section{IV. 결론}

테러리즘을 국제개발협력의 시각에서 접근하는 것이 과연 올바른가라는 회의적인 시각이 있을 수 있다. 다시 말하지만, 테러리즘을 근절하기 위해서는 국제개발협력만 으로는 한계가 있다. 그럼에도 불구하고 테러리즘의 해법으로 국제개발협력을 끌어 들이는 이유는 무엇보다 테러리즘이 분쟁을 온상으로 하고 있는 현실 때문이다. 현 재 테러리즘은 분쟁을 온상으로 세력과 활동 범위를 확대하고 있고, 분쟁을 틈타 테 러를 포함해 살인, 강도, 인질, 밀수 등 조직화한 범죄를 저지르고 있다. 그리고 이 것이 역으로 분쟁을 가중 또는 영속화하면서 국제개발협력을 저해하고 있다. 역설적 이게도 이것은 테러의 온상인 분쟁 해결 없이는 테러리즘도 해결하기 어렵다는 것을 의미한다. 마침 본문에서 언급한 〈뉴딜〉을 비롯해 MDGs 이후 국제개발협력의 틀을 논의하는 'Post-2015'에서 평화와 안보가 주요 의제 중 하나로 다뤄지고 있는 데서 엿볼 수 있듯이 분쟁이 국제개발협력 공동체에서 중요 사안으로 인식되고 있다.

테러리즘을 국제개발협력의 맥락에서 이야기하는 또 다른 이유는 '알카에다 3.0'의 출현이 말해주듯 강공일변도였던 기존의 대테러리즘이 실패, 또는 실패는 아니더라 도 한계를 드러냈다는 것이다. 2001년 9/11 테러 직후 미국은 오사마 빈 라덴과 알 카에다를 제거하고 이를 배후에서 지원하고 있는 탈레반을 몰아내기 위해 아프가니 스탄 전쟁을 감행했다. 그런데 미국이 아프가니스탄 전쟁에서 얻은 것이라고는 알카 에다를 조직하고 $9 / 11$ 테러를 기획한 오사마 빈 라덴 사살 외에 아무 것도 없다. 오히 려 13 년 넘게 이어진 전쟁으로 재정적자가 천문학적으로 늘어나면서 국내 여론의 비 판에 직면했고, 대테러리즘의 실패로 인해 국제적 위상도 떨어질 데로 떨어졌다. 이 로 인한 인명 피해는 두말할 것도 없다. 반면, 알카에다는 오사마 빈 라덴 사망 이후 에 프랜차이즈화와 네트워크화 전략을 통해 자생적인 조직으로 거듭났고, 심지어는 케냐 나이로비 쇼핑몰 테러처럼 다국적 또는 초국적 성향을 띠기 시작했다. 대테러 리즘 전략의 수정이 시급히 요구되는 대목이다. 여하튼, 테러리즘 조직이 과거 중앙 집권적인 경성 조직에서 연성 조직으로 탈바꿈한 마당에 더 이상 강공일변도로는 분 명 한계가 있다. 
따라서 테러리즘을 해소하기 위해서는 테러리즘의 온상이 되고 있는 분쟁 해소 노 력과 더불어 다소 유연한 대테러리즘 전략이 요구된다. 분쟁 해소 노력과 유연한 대 테러리즘 전략이 효과가 있기 위해서는 반목과 대립이 아닌 이해와 포용, 그리고 대 화가 전제돼야 한다. ${ }^{8)}$ 다시 말해, 테러리즘의 온상이 되고 있는 분쟁이 국제개발협 력이라는 국제사회의 공동노력으로 해소된다고 해도 대테러리즘이 강공일변도로 유 지된다면 테러리즘은 해소하기 어렵다. 테러리즘이 발생하는 근본적인 원인을 국제 정치적 맥락에서 파악하고 해결하려는 노력이 병행돼야 하는 이유다. 이슬람 극단주 의도 문제이기는 하지만, 기존의 서구 중심적인 오리엔탈리즘도 문제이기는 마찬가 지다. 서로 다른 종교, 이데올로기, 정치체제가 공존할 수 있는 국제적인 제도나 규 범이 마련되어야 한다. 요약하면, 국제개발협력의 맥락에서 테러리즘의 온상이 되고 있는 분쟁 해결 노력과 국제정치적 맥락에서 다양한 세력들이 대화하고 협상할 수 있는 제도나 규범을 만들기 위해 노력해야 한다. 인도주의에 입각해 가난한 나라들 의 빈곤, 불평등, 저개발, 분쟁을 해소하기 위해 원칙, 제도, 규범을 만들어 협력하 고 있는 국제개발협력이 대테러리즘 전략에 시사하는 것이 바로 이것이다.

8) 매리 캘도어나 폴 콜리어는 이를 위한 국제사회의 노력을 '세계시민사회’의 관점에서 이야기한다. 즉, 세계화한 시대에 국가 간의 분쟁을 포함해 초국적인 분쟁들을 평화롭 게 해결하기 위해서는 민주사회의 원동력으로 대화와 협력, 포용을 미덕으로하는 시민 의식이 전제돼야 한다는 것이다. 


\section{참고문헌}

\section{- 국내문헌}

김영미(2013a), “알카에다는 프랜차이즈 조직”, 『시사IN』 204호, http:// www. sisainlive.com/news/articleView.html?idxno=10936(검 색일: 2014.7.20).

김영미(2013b), ‘지금 아프리카는 “더 테러 라이브”, 『시사IN』 318호, http://www. sisainlive.com/news/articleView. html?idxno=18 103(검색일: 2014.7.25).

\section{- 국외문헌}

Bajora, Jayshree and Bruno, Greg(2012), "al-Qaeda", Council on Foreign Relations, http://www.cfr.org/terroristorganizations-and-networks/al-qaeda-k-al-qaida-alqaida/p9126\#(검색일: 2014.8.6).

Bruce Riedel(2012), 'Al Qaeda 3.0: Terrorism's Emergent New Power Bases', The Daily Beast, http://www. thedailybeast.com / articles/2012/12/03/al-qaeda-3-0-terrorism-semergent-new-power-bases.html(검색일: 2014.7.24).

Geneva Declaration Secretariat(2011), Global Burden of Armed Violence 2011, Cambridge: Cambridge University Press.

Harding, Andrew(2013), "Somalia and Kenya: Blood Brothers", BBC, http://www.bbc.com/news/world-africa-24330273(검색일: 2014.8.6).

Huntington P., Samuel(2011), The Clash of Civilizations and the Remaking of World Order, New York: Touchstone.

Mary Kaldor(2006), New \& Old Wars: Organized Violence in a Global

Era, Cambridge: Polity Press; 유강은 역(2010), 『새로운 전 쟁과 낡은 전쟁』, 서울: 그린비.

Paul Collier(2008), Bottom Billion, Oxford: Oxford University Press; 류 현 역(2010), 『빈곤의 경제학』, 서울: 살림. 
Piazza A., James(2006), "Rooted in Poverty?: Terrorism, Poor Economic Development, and Social Cleavages", Terrorism and Political Violence, Vol. 18, pp. 159-177.

Said, Edward(1979), Orientalism, New York: Random House, Inc. Sandler, Todd and Enders, Walter(2008), "Economic Consequences of Terrorism in Developed and Developing Countries: An Overview", Keefer, Philip and Loayza, Norman eds., Terrorism, Economic Development, and Political Openness, Cambridge: Cambridge University Press, pp. $17-47$.

Slotin, Jenna and Elgin-Cossart, Molly(2013), "Why Would Peace Be Controversial at the United Nations? Negotiations Toward a Post-2015 Development Framework", Center on International Cooperation of New York University.

Susan G. Chesser(2012), "Afghanistan Casualties: Military Forces and Civilians", Congressional Research Service.

The Fund for Peace(2014), The Fragile State Index 2014, Washington, DC: The Fund for Peace.

Thomson, Mark(2013), "The Danger of the Lone-Wolf Terrorist", Time, http://nation. time.com/2013/02/27/the-danger-of-the-lo ne-wolf-terrrorist/(검색일: 2014.8.6)

UN General Assembly(2013), A Life of Dignity for All, Report of General-Secretary, New York: United Nations.

UN System-wide Task Force(2012), Realizing the Future We Want for All, Report to the Secretary-General, New York: United Nations.

UNHLP(2013), A New Global Partnership: Eradicate Poverty and Transform Economies Through Sustainable Development, The Report of the High-Level Panel of Eminent Persons on the Post-2015 Development Agenda, New York: United Nations.

World Bank(2011), Conflict, Security, and Development, Washington, DC: The World Bank. 